\title{
MINIBIOTUS ACADIANUS (EUTARDIGRADA: MACROBIOTIDAE), A NEW SPECIES OF TARDIGRADA FROM SOUTHERN LOUISIANA, U.S.A.
}

\author{
Harry A. Meyer ${ }^{1,2}$ and Megan N. Domingue ${ }^{1}$
}

\begin{abstract}
Over 200 species of freshwater and terrestrial water bears (phylum Tardigrada) are known to occur in North America. Of these, 16 species have been collected in Louisiana. Foliose and fruticose lichens collected on 18 April 2010 in Acadia Parish, Louisiana, were stored in paper envelopes and later soaked in tap water overnight. Tardigrade specimens and eggs were extracted and mounted in polyvinyl lactophenol. The samples contained a new species of tardigrade. Minibiotus acadianus sp. $\mathbf{n}$. has a buccal tube with single anterior curvature, 2 macroplacoids and 1 microplacoid. Small gibbosities are present on the fourth pair of legs, in 3 caudal rows, and in a single row at the level of the third pair of legs. Minibiotus acadianus sp. n. differs from the most similar tardigrade species, Minibiotus fallax (found in Australia and Florida), in having a shorter and wider buccal tube, a different pattern of gibbosities, and short, peg-shaped processes in addition to long, filamentous processes on the eggs. Reexamination of specimens identified as M. fallax in an earlier paper on the Tardigrada of Louisiana indicates that they are, in fact, $M$. acadianus sp. n., suggesting that the new species is widely distributed in Louisiana.
\end{abstract}

RESUMEN.-Se conocen más de 200 especies de osos de agua (phylum Tardigrada) terrestres y de agua dulce que ocurren en Norteamérica. De éstas, 16 se han colectado en Louisiana. Se colectaron líquenes foliosos y fruticosos en la parroquia de Acadia, Louisiana, el 18 de abril de 2010, los cuales fueron guardados en sobres de papel y después remojados en agua de la llave durante toda la noche. Se extrajeron especímenes y huevos de tardígrados y se fijaron en polivinilo lactofenol. Las muestras contenían una nueva especie de tardígrado. Minibiotus acadianus $s p$. $n$. tiene un tubo bucal con una única curvatura anterior, dos macroplacoides y un microplacoide. Pequeñas gibosidades están presentes en el cuarto par de patas, en tres hileras caudales y en una sola hilera al nivel del tercer par de patas. Minibiotus acadianus $s p$. $n$. difiere de la especie más próxima, Minibiotus fallax, una especie que se encontró en Australia y Florida, porque tiene un tubo bucal más corto y ancho, un patrón distinto de gibosidades y apófisis cortas en forma de estaquilla en los huevos, además de apófisis largas y filamentosas. Una reexaminación de los especímenes identificados como M. fallax en una publicación previa sobre los tardígrados de Louisiana indica que son más bien M. acadianus sp. n., lo cual sugiere que esta nueva especie tiene una distribución extensa en Louisiana.

Tardigrades (phylum Tardigrada), commonly known as water bears, are microscopic animals found in marine, freshwater, and terrestrial habitats. Terrestrial species occur in mosses, lichens, liverworts, and leaf litter, and are renowned for their ability to enter a cryptobiotic state (anhydrobiosis) in response to desiccation. Terrestrial tardigrades include both herbivorous and carnivorous species that feed on nematodes, rotifers, and other tardigrades (Lehmann et al. 2007). Over 200 species of freshwater and terrestrial tardigrade are known to occur in North America (Meyer and Hinton 2007). Of these, 16 are known to occur in Louisiana (Meyer 2001, Hinton and Meyer 2007).

We describe a new species belonging to the genus Minibiotus collected from lichens in Acadia Parish, Louisiana, southeastern United States (in Louisiana, a parish is a unit of local administration corresponding to a county in other American states). Only one species of water bear, Milnesium tardigradum, has been found previously in Acadia Parish (Hinton and Meyer 2007).

\section{Methods}

The second author collected lichen samples in Crowley, Acadia Parish, Louisiana, on 18 April 2010; sampling was not quantitative. The foliose lichen Parmotrema perforatum (Jacq.) A. Massal. and the fruticose lichen Ramalina stenospora Müll. Arg. were collected from trees and fallen branches. Samples were stored in sealed paper envelopes or paper bags.

In the laboratory, samples were placed in tap water and soaked overnight to rehydrate anhydrobiotic water bears. After sieving $(42-\mu \mathrm{m}$

${ }^{1}$ Department of Biology and Health Sciences, McNeese State University, Lake Charles, LA 70609

2E-mail: hmeyer@mcneese.edu 

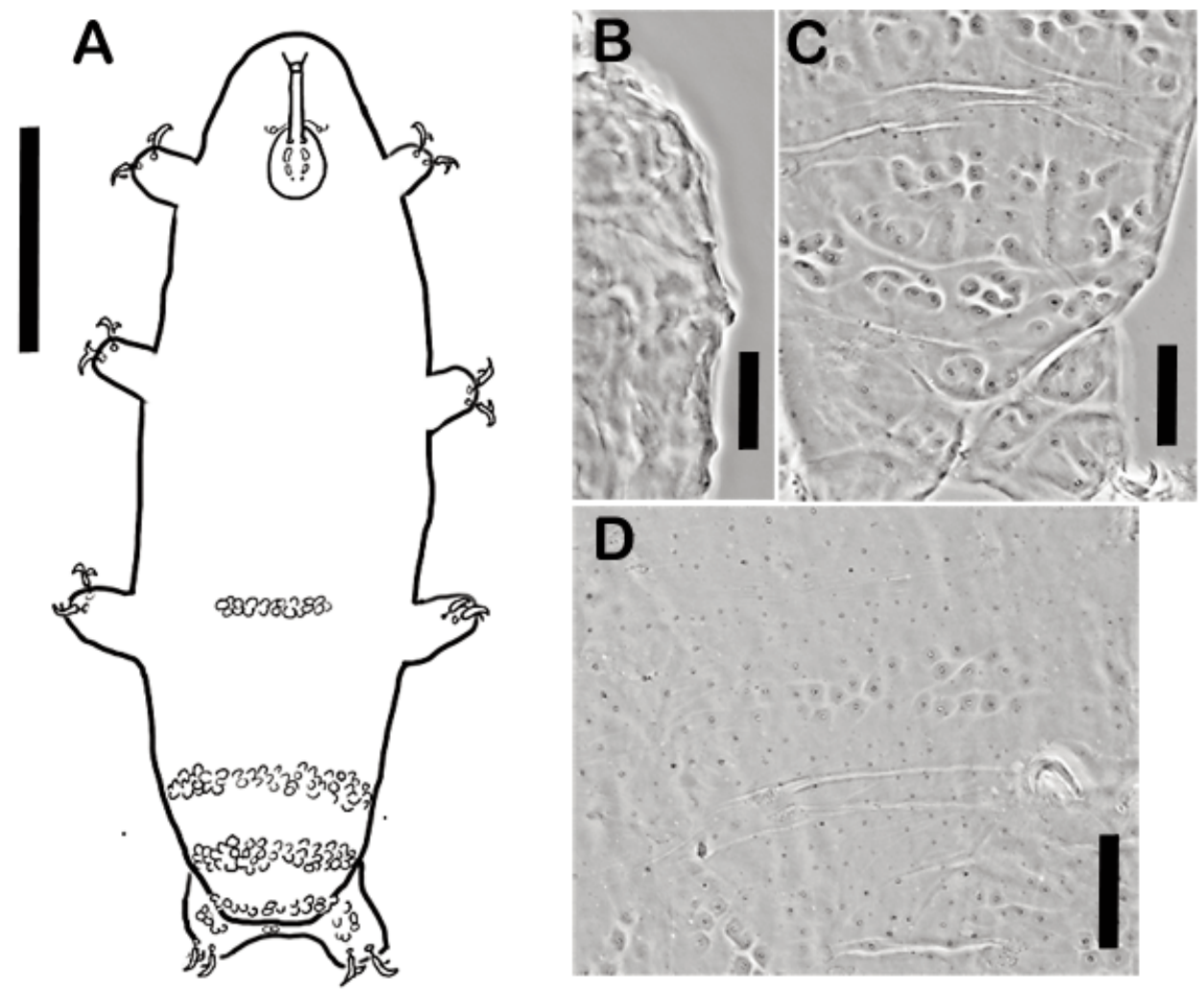

Fig. 1. Minibiotus acadianus sp. n.: A, habitus; B, posterior gibbosities; lateral view of dorsum near leg II; C, posterior and leg IV gibbosities, dorsal view; D, gibbosities at level of leg III. Scale bars: A, $100 \mu \mathrm{m} ; \mathrm{B}-\mathrm{D}, 20 \mu \mathrm{m}$.

mesh diameter), the samples were examined with a dissecting microscope for the presence of tardigrade specimens and eggs. Specimens and eggs were mounted on slides in polyvinyl lactophenol and examined under oil immersion using a phase-contrast microscope. Anatomical terminology follows Guidetti and Bertolani (2005). Specimens were measured using imaging software (NIS-Elements D 2.30, SPI), and all morphological measurements are given in micrometers $(\mu \mathrm{m})$. The $p t$ index, expressed as a percentage, is the ratio of the length of a given structure to that of the buccal tube (Pilato 1981). In type descriptions, $p t$ indices are put in bracketed italics. Buccal tube length was measured from the anterior margin of the stylet sheaths to the base of the tube, while the stylet insertion point was measured from the anterior margin of the stylet sheaths to the point of insertion on the buccal tube. Buccal tube width was measured as the external diameter at the level of stylet support insertion. Lengths of primary and secondary branches of claws were measured from base to apex, including accessory points.

\section{Taxonomic Account}

\section{Minibiotus acadianus sp. $\mathrm{n}$.}

(Figs. 1-3, Tables 1-2)

Diagnosis.-A Minibiotus species with 2 macroplacoids and 1 microplacoid; gibbosities on the fourth pair of legs, in 3 caudal bands, and in a band at the level of the third pair of legs; eggs with short, peg-shaped processes and sometimes long, filamentous processes.

MATERIAL EXAMINED.-One holotype, 8 paratypes, and 9 eggs (including 1 embryonate egg): foliose and fruticose lichen from trees and fallen branches in a wooded lot behind Woodlawn Cemetery on South Avenue F, Crowley, Acadia Parish, Louisiana, U.S.A. $\left(30^{\circ} 11^{\prime} 30.23^{\prime \prime} \mathrm{N}, 92^{\circ}\right.$ $22^{\prime} 23.43^{\prime \prime} \mathrm{W}$; elevation $20 \mathrm{~m}$ asl).

DEPOSIT OF TYPES.-The holotype (SMLA 9560) and paratypes (SMLA 9550, 9552, 9555, 

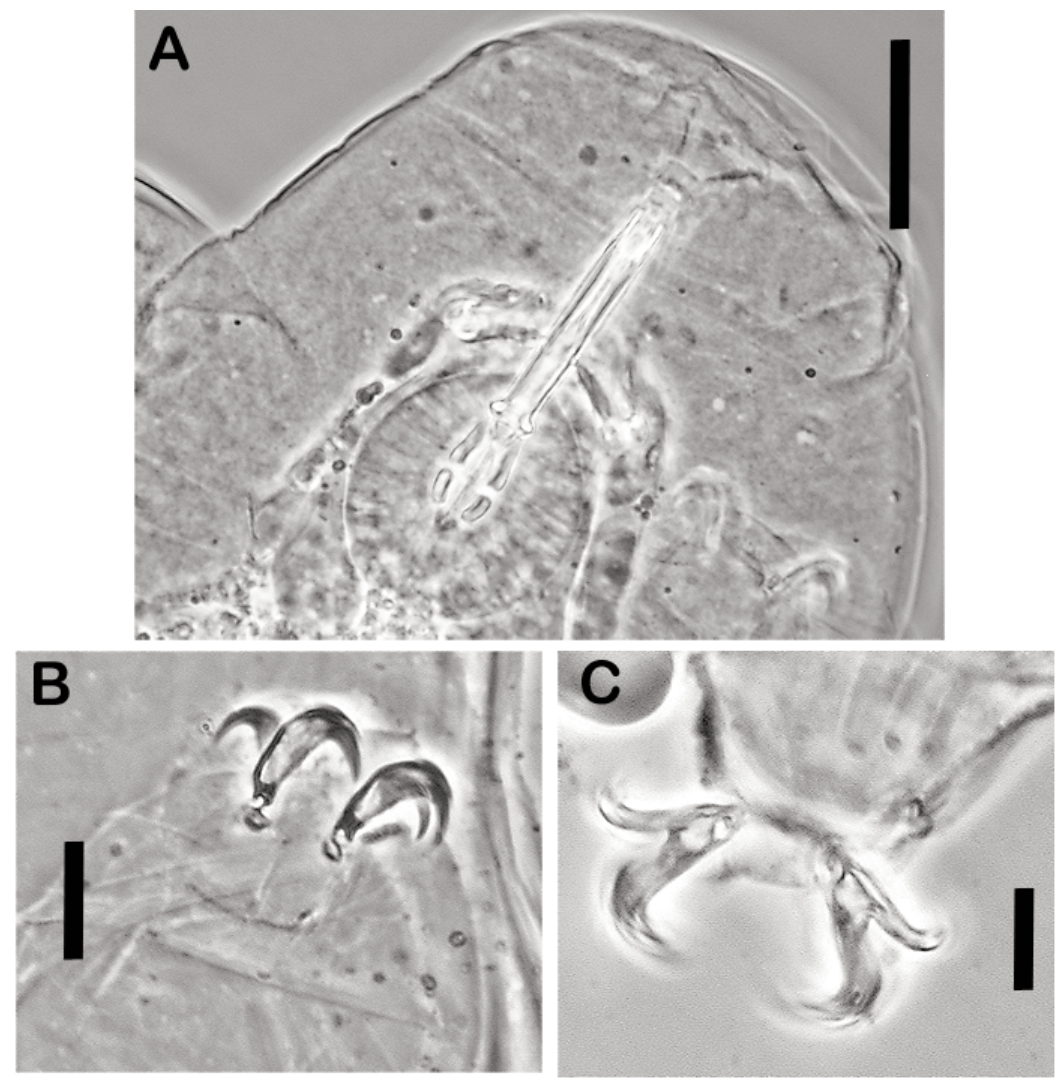

Fig. 2. Minibiotus acadianus sp. n.: A, buccopharyngeal apparatus; B, claw of leg II; C, claw of leg IV. Scale bars: A, $20 \mu \mathrm{m} ; \mathrm{B}-\mathrm{C}, 10 \mu \mathrm{m}$.

TABLE 1. Morphometric data and $p t$ values of selected characters of 9 specimens of Minibiotus acadianus $\mathbf{s p .} \mathbf{n}$. from Acadia Parish, Louisiana, USA. Characters are lengths $(\mu \mathrm{m})$ unless otherwise indicated. Range refers to the smallest and largest structure found among all measured specimens. Abbreviations: $N=$ number of specimens measured, $\mathrm{SD}=$ standard deviation, n.a. $=$ not applicable, $p t=p t$ index.

\begin{tabular}{|c|c|c|c|c|c|c|c|}
\hline \multirow[b]{2}{*}{ Character } & \multirow[b]{2}{*}{$N$} & \multicolumn{2}{|c|}{ Range } & \multicolumn{2}{|c|}{ Mean } & \multicolumn{2}{|c|}{ SD } \\
\hline & & Length & $p t$ & Length & $p t$ & Length & $p t$ \\
\hline Body & 9 & $285.0-445.4$ & n.a. & 365.3 & n.a. & 56.7 & n.a \\
\hline Buccal tube & 9 & $26.0-28.2$ & n.a. & 28.2 & n.a. & 1.4 & n.a \\
\hline Stylet support insertion point & 9 & $17.8-20.4$ & $66.0-71.1$ & 19.3 & 68.6 & 0.8 & 1.9 \\
\hline Buccal tube external diameter & 9 & $2.6-4.2$ & $10.4-13.6$ & 3.6 & 12.6 & 0.4 & 1.0 \\
\hline First macroplacoid & 9 & $5.3-6.8$ & $19.3-22.4$ & 5.9 & 21.1 & 0.5 & 1.4 \\
\hline Second macroplacoid & 9 & $3.4-4.4$ & $12.5-15.7$ & 4.0 & 14.1 & 0.3 & 1.0 \\
\hline Macroplacoid row & 9 & $9.4-11.7$ & $35.4-39.4$ & 10.5 & 37.3 & 0.8 & 1.4 \\
\hline Microplacoid & 9 & $1.0-2.1$ & $3.8-7.4$ & 1.6 & 5.5 & 0.4 & 1.2 \\
\hline Placoid row & 9 & $11.0-14.0$ & $41.7-49.3$ & 12.5 & 44.5 & 1.1 & 2.8 \\
\hline Primary claw branch, Leg I & 4 & $9.7-11.5$ & $36.2-42.0$ & 10.7 & 39.7 & 0.8 & 2.6 \\
\hline Secondary claw branch, Leg I & 4 & 8.1-9.6 & $30.2-33.8$ & 9.0 & 32.3 & 0.6 & 1.7 \\
\hline Primary claw branch, Leg II & 6 & $10.9-12.0$ & $39.2-43.5$ & 11.5 & 41.2 & 0.4 & 1.7 \\
\hline Secondary claw branch, Leg II & 6 & $9.2-10.4$ & $30.4-35.6$ & 9.6 & 33.6 & 0.4 & 1.9 \\
\hline Primary claw branch, Leg III & 4 & $10.8-12.1$ & $36.9-43.1$ & 11.5 & 40.7 & 0.6 & 2.8 \\
\hline Secondary claw branch, Leg III & 4 & $8.3-10.1$ & $26.9-35.6$ & 9.2 & 32.6 & 0.7 & 3.9 \\
\hline Primary claw branch, Leg IV & 5 & $11.0-13.2$ & $42.3-47.8$ & 12.7 & 45.6 & 0.7 & 2.2 \\
\hline Secondary claw branch, Leg IV & 5 & $9.2-10.7$ & $34.6-37.7$ & 9.9 & 36.4 & 0.7 & 1.2 \\
\hline
\end{tabular}



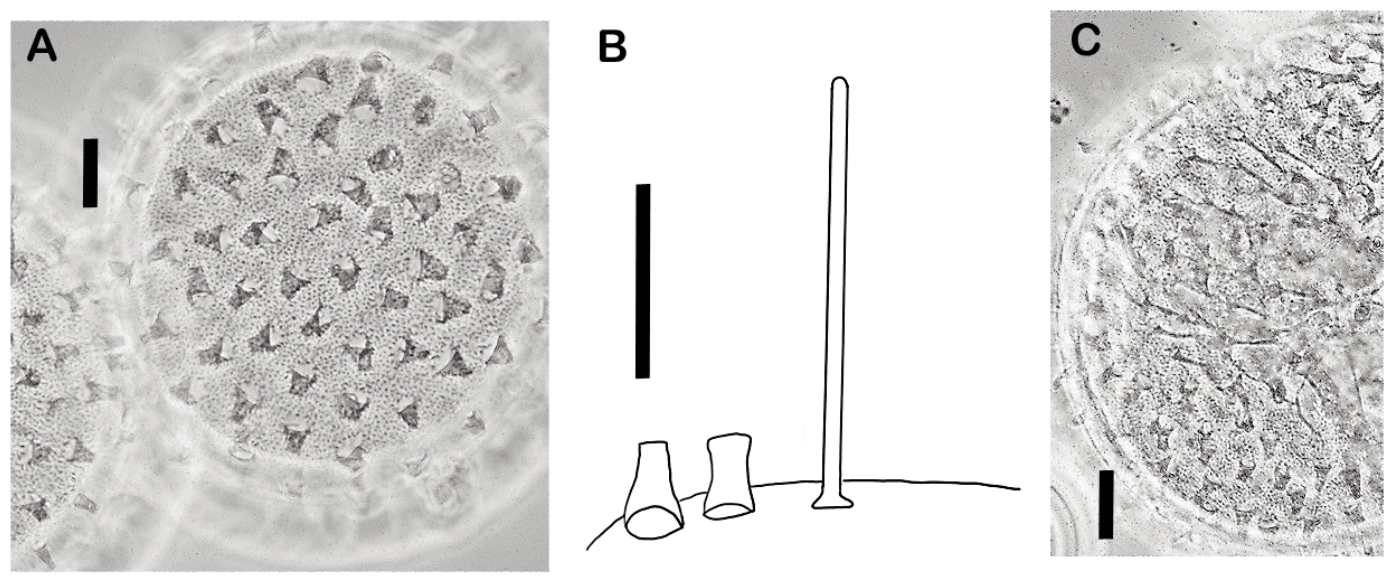

Fig. 3. Minibiotus acadianus sp. n.: A, egg with peg-shaped processes; B, egg processes; C, egg with mixed peg-shaped and filamentous processes. Scale bars: $10 \mu \mathrm{m}$.

TABLE 2. Morphometric data of selected structures of 8 eggs of Minibiotus acadianus sp. n. from Acadia Parish, Louisiana, USA. Diameter, height, and distance in micrometers $(\mu \mathrm{m})$. Range refers to the smallest and largest structure found among all measured specimens.

\begin{tabular}{ll}
\hline Character & Range \\
\hline Diameter without processes & $38.0-72.8$ \\
Diameter with processes & $43.6-79.9$ \\
Height of peg-shaped processes & $2.0-4.4$ \\
Diameter of peg-shaped process bases & $2.2-4.3$ \\
Length of filamentous processes & $5.1-17.1$ \\
Diameter of filamentous process bases & $1.5-2.5$ \\
Distance between processes & $1.7-4.7$ \\
Number of processes around circumference & $28-38$ \\
Approx. number of processes in hemisphere & $75-110$ \\
\hline
\end{tabular}

9557-9561) are deposited in the W.A.K. Seale Museum, Department of Biology and Health Sciences, McNeese State University, Lake Charles, Louisiana 70609, U.S.A.

DESCRIPTION.-Holotype: body length 414.7, white or transparent (Fig. 1A). Eyes absent. Cuticle with numerous small circular pores (approximately 1.0 wide). Gibbosities present in 3 caudal rows of variable width and on fourth pair of legs (Figs. 1B, 1C). Additional band of gibbosities at level of third pair of legs (Fig. 1D). Most gibbosities polygonal or elliptical, 3.1-4.8 wide, with well-developed central pore. Some gibbosities fused into larger formations, maximum measured 9.1 long by 4.1 wide.

Mouth anteroventral. Oral cavity teeth absent or not visible with light microscopy. Buccal tube rigid, with single anterior curvature, 30.9 long, 4.2 [13.6] wide (Fig. 2A). Buccal tube wall thickened below stylet support insertion point. Stylet supports inserted on buccal tube at 20.4 [66.0]. Ventral support inserted at 15.6 [50.5]. Apophyses in pharynx triangular, close to first macroplacoid. First macroplacoid rod shaped, with central constriction, 6.8 [22.2] long; second rod shaped, with subterminal constriction, 4.4 [14.2] long. Macroplacoid row 11.7 [37.9] long. Microplacoid shaped like an elongated tear drop, 1.8 [5.8] long. Entire placoid row 13.3 [43.0] long. Pharyngeal bulb round, 32.9 [106.5] wide, 34.1 [110.4] long.

Granulation present on all legs. Claws of hufelandi type short and stout, with welldeveloped accessory points on primary branches (Figs. 2B, 2C). Claw lengths: leg II primary branch (pb) 12 [43.5], secondary branch (sb) 9.4 [30.4]; leg III pb 11.4 [36.9], sb 8.3, 26.9]; leg IV pb 13.7 [42.7], sb 10.7 [34.6]. Claw lunules small, smooth edged. Lunule widths: leg II 2.5 [8.1], leg III 2.1 [6.8], leg IV 2.7 [8.7].

Morphometric data and summary statistics for the holotype and 8 paratypes are given in Table 1.

Eggs white or transparent, laid freely. Surface punctate (Fig. 3A). Two types of processes: short, peg-shaped processes (Fig. 3A, 3B) and thin, blunt-ended filamentous processes (Fig. 3B, 3C). Peg-shaped processes always present, with uniform distribution (Fig. 3A). Filamentous processes sometimes absent, sometimes sparse, sometimes abundant (Fig. 3C). Measurements of some structures from 8 eggs are given in Table 2 . The presence of embryonation (buccal tube and placoids) in one egg makes the assignment 
of these eggs to Minibiotus acadianus sp. n. definitive.

DifFERENTIAL Diagnosis.-Guidetti et al. (2007) listed a suite of 10 characters shared by most, though not all, species of Minibiotus. These characters are (1) anteroventral mouth, (2) oral cavity teeth absent or strongly reduced, (3) rigid, narrow buccal tube (width $p t \leq 12$ ), (4) buccal tube thickened below the point of insertion of stylet supports, (5) stylet supports inserted at a considerable distance from the posterior end of the buccal tube $(p t \leq 73)$, (6) short ventral lamina ( $p t \leq 73)$, (7) short macroplacoid row length $(p t \leq 42)$, (8) double curvature of the buccal tube, (9) first macroplacoid located very close to the pharyngeal apophyses, and (10) 3 almost rounded macroplacoids. Minibiotus acadianus sp. n. exhibits characters $1,2,4,5,6,7$, and 9. However, it has 2 macroplacoids, and its buccal tube is somewhat wider (mean $p t=12.6$ ) and has only one curvature.

Most species of Minibiotus have 3 macroplacoids, a character which differentiates them from Minibiotus acadianus sp. n. Only Minibiotus scopulus Claxton, 1998; M. africanus Binda and Pilato, 1995; M. diphasconides (Iharos, 1969); and M. fallax Pilato, Claxton, and Binda, 1989, have 2 macroplacoids. The presence of posterior gibbosities differentiates Minibiotus acadianus sp. n. from M. scopulus, M. africanus, and M. diphasconides.

Minibiotus acadianus sp. n. most closely resembles Minibiotus fallax; in the most recently published key to Minibiotus (Claxton 1998), the new species keys out to the space occupied by M. fallax. Both species have posterior bands of gibbosities, cuticles with numerous small pores, and eggs with punctate shells and long, thin processes (Pilato et al. 1989). The 2 species can be distinguished by several independent characters:

1. Minibiotus acadianus sp. $\mathrm{n}$. has a buccal tube that is shorter (in specimens of comparable size, 28.2 in the new species and 30.6 in M. fallax) and wider (in specimens of comparable size, 3.6 [pt 12.6] in the new species and 2.9 [pt 9.2] in $M$. fallax). The stylet support insertion point is more posterior in the new species ( $p t$ 66.0-71.1 in M. acadianus sp. n. and pt 62.8-66.6 in M. fallax).

2. Gibbosities extend forward as far as the second pair of legs in M. fallax but only as far as the third in the new species. Gibbosities are present on the fourth pair of legs in M. acadianus sp. n. but not in $M$. fallax. The largest gibbosity measured in M. fallax is 15.8 long by 10.0 wide; the largest gibbosity in $M$. acadianus sp. n. is 9.1 by 4.3 .
3. Eyes and bands of pigment are present in M. fallax but not in the new species.

4. The numerous short, peg-shaped processes in the eggs of M. acadianus are not present in M. fallax.

REMARKS.- Tardigrades with narrow buccal tubes, including species in the genus Minibiotus, are known to feed on plant material (Lehmann et al. 2007). Feeding has not been observed in Minibiotus acadianus sp. n., but the narrowness of its buccal tube suggests that it is probably an herbivore.

ETYMOLOGY.-The specific name acadianus is a masculine adjective commemorating both Acadia Parish and Acadiana, the region of southern Louisiana known for its large Cajun population.

\section{Discussion}

Meyer (2008) found Minibiotus fallax specimens and eggs in Florida, including the far western counties. The species has not been reported from Mississippi or Alabama (Hinton and Meyer 2007, 2009). Hinton and Meyer (2007) reported the presence of Minibiotus fallax, but no eggs, in cryptogams from East Feliciana, Iberia, Iberville, Ouachita, Richland, St. Bernard, Vermillion, and Vernon parishes in Louisiana. Reexamination of the Louisiana specimens indicates that they are Minibiotus acadianus sp. n., suggesting that the new species is distributed widely in the state.

Hinton and Meyer (2007) hypothesized that 4 species (Echiniscus cavagnaroi Schuster and Grigarick, 1966, Echiniscus kofordi Schuster and Grigarick, 1966, Minibiotus fallax, and an undescribed Macrobiotus cf. hufelandi) constitute a distinctive regional tardigrade fauna within North America. We now add Minibiotus acadiamus sp. n. to this list. We also hypothesize that the border between the distributions of Minibiotus acadianus sp. n. and Minibiotus fallax occurs somewhere from eastern Louisiana to Alabama.

\section{ACKNOWLEDGMENTS}

We thank Sandra Claxton for providing us with a specimen and egg of Minibiotus fallax for use in our comparison. Denise Domingue and Richard Doss assisted with field collection of the lichen samples. 


\section{Literature Cited}

Claxton, S. 1998. A revision of the genus Minibiotus (Tardigrada: Macrobiotidae) with description of eleven new species from Australia. Records of the Australian Museum 50:125-160.

Guidetti, R., AND R. Bertolani. 2005. Tardigrade taxonomy: an updated checklist of the taxa and a list of characters for their identification. Zootaxa 845:1-46.

Guidetti, R., R. Bertolani, and P. Degma. 2007. New taxonomic position of several Macrobiotus species (Eutardigrada: Macrobiotidae). Zootaxa 1471:61-68.

Hinton, J.G., AND H.A. Meyer. 2007. Distribution of limnoterrestrial Tardigrada in Georgia and the Gulf Coast states of the United States of America with ecological remarks. Journal of Limnology 66 (Supplement 1):72-76.

2009. Tardigrada of Mississippi. Proceedings of the Louisiana Academy of Sciences 67:23-27.

Lehmann, R.E., S.D. Shively, AND W.R. Miller. 2007. Tardigrades of North America: an historical collection from Kansas and Missouri. Transactions of the Kansas Academy of Science 110:169-178.

MeYER, H.A. 2001. Tardigrades of Louisiana and Arkansas, United States of America. Zoologischer Anzeiger 540: 471-474.

2008. Distribution of tardigrades in Florida. Southeastern Naturalist 7:91-100.

Meyer, H.A., And J.G. Hinton. 2007. Limno-terrestrial Tardigrada of the Nearctic Realm. Journal of Limnology 66 (Supplement 1):97-103.

PiLATO, G. 1981. Analisi di nuovi caratterri nello studio degli Eutardigrada. Animalia 8:51-57.

Pilato, G., S. Claxton, and M.G. Binda. 1989. Tardigrades from Australia. II. The evaluation of Calohypsibius ornatus (Richters, 1900) caelatus (Marcus, 1928) as a valid species and description of Minibiotus fallax $\mathrm{n}$. sp. (Eutardigrada). Animalia 16:21-27.

Received 27 July 2010 Accepted 12 November 2010 